Article

\title{
Bromatological, Proximate and Ultimate Analysis of OFMSW for Different Seasons and Collection Systems
}

\author{
Isabella Pecorini * E , Elena Rossi and Renato Iannelli * \\ DESTEC-Department of Energy, Systems, Territory and Construction Engineering, University of Pisa, \\ 56122 Pisa, Italy; elena.rossi@phd.unipi.it \\ * Correspondence: isabella.pecorini@unipi.it (I.P.); renato.iannelli@unipi.it (R.I.); Tel.: +39-050-221-7926
}

Received: 8 March 2020; Accepted: 24 March 2020; Published: 26 March 2020

\begin{abstract}
In order to study the quality of organic fractions of municipal solid waste (OFMSW), five different municipalities in Tuscany were chosen for sampling according to the peculiarities of their collection systems. The five collection systems selected were sampled four times: during March, June, September and December, for a total of 20 picking analyses. In addition, emphasis was also given to the study of the variability of OFMSW composition related to ultimate, proximate and bromatological analyses. Road container collection systems proved to have a higher content of non-compostable and undesirable fractions $(22 \% \pm 1 \%)$ when compared to door-to-door systems $(6 \% \pm 1 \%)$. During months with lower temperature (March and December), the garden waste content in the OFMSW was negligible, with kitchen waste prevailing. This altered the physical chemical composition of OFMSW, which had a lower lignin content and higher methane production in the months with lower temperatures (272 $\left.\pm 23 \mathrm{NLCH}_{4} \mathrm{~kg}_{\mathrm{TVS}}{ }^{-1}\right)$ compared to June and September $\left(238 \pm 14 \mathrm{NLCH}_{4} \mathrm{~kg}_{\mathrm{TVS}}{ }^{-1}\right)$. In general, the Tuscan OFMSW had a higher dry matter content (42\%) than observed in previous studies. In conclusion, the result could direct possible future operators of anaerobic digestion plants towards the choice of dry and semi-dry technologies.
\end{abstract}

Keywords: anaerobic digestion; food waste; garden waste; organic waste characteristics; physical-chemical characteristics; methane production

\section{Introduction}

The organic fraction of municipal solid waste (OFMSW) is the single largest component of the waste stream by weight in the European Union where about 96 million tons are thrown away each year [1]. In 2018, the production of source-separated (SS) OFMSW in Italy, was about 7 million $t$ amounting to approximately $40 \%$ of MSW. The composition of the SS OFMSW was made up of about $70 \%$ from kitchen and canteen waste and 30\% from garden and park waste. In 2018, 51.6\% of OFMSW was treated in composting plants, $43.6 \%$ in anaerobic-aerobic integrated plants and finally $4.8 \%$ in anaerobic digestion (AD) plants [2]. For a correct transition towards the circular economy [3] and towards the concept of anaerobic biorefinery [4,5], many composting plants are currently planning revamping in a move towards the integrated aerobic/anaerobic system or towards AD [6].

AD turns organic matter into two valuable products: (a) energy-rich biogas, a renewable fuel which can be used to generate electricity, heat or as a substitute for natural gas and transportation fuel and (b) nutrient rich digestate, which can be utilized directly or composted before use in landscaping or agriculture [7]. Although anaerobic digestion is a promising technology for the treatment of OFMSW, there are disadvantages such as the difficulty in starting digesters [8], the increase in stabilization times [9] and the presence of toxic or inhibiting compounds when impurities are not properly removed 
from OFMSW [10]. In accordance with to the circular economy approach, it is essential to produce a good digestate for agronomic purposes and this can happen if the OFMSW is of good quality. For this reason it is necessary to investigate the factors driving the feedstock characteristics [10]. The design and performance of AD plants is also influenced by features related to feedstock. In order to design and manage an anaerobic digester, physical characteristics of the OFMSW is important as it influences biogas production and process stability [11]. In addition, characterization of OFMSW properties need to be cognizant with the regional, seasonal and socio-economic contexts. The physical, chemical, elemental and bromatological characteristics of OFMSW from 43 cities in 22 countries have been compiled by Campuzano and González- Martínez [12,13], the variation in waste characteristics being ascribed to the different cultural lifestyles and waste management systems found in these countries. Such variation does not, therefore, allow a generalization of the waste characteristics. Site-specific analyses do provide a better understanding of the characteristics of a particular waste, which would be necessary for activities such as better biogas recovery $[7,14]$.

In order to characterize the Tuscan OFMSW in depth, it was decided to perform the ultimate and proximate analysis. Both are widely recognized as valid characterization methodologies and have been extensively used also in other fields of application such as in fuel industry to study the components of petroleum after completion of production $[15,16]$ or those of coal after complete combustion [17].

A thorough knowledge of the chemical composition of OFMSW is of primary importance as it influences both the kinetics of the AD process and the quality of the digestate [13]. Many studies have generally carried out both physical and chemical analysis of food waste $[4,11,18-20]$ while few have analyzed OFMSW $[7,13]$. There has been, moreover, very little investigation carried out into the composition of OFMSW based on seasonal variability and the type of collection system.

For this reason, the main objective of this work is to assess whether different collection models can influence the quality of OFMSW as AD feedstock and its specific biogas production [21-24]. In addition, emphasis has also been given to the study of the seasonal variability of OFMSW composition related to ultimate, proximate and bromatological analysis [23], with the overall aim of providing the designers and operators of future anaerobic digestion plants with more information.

\section{Materials and Methods}

\subsection{Study Area Description}

In order to study the quality of OFMSW, 5 different municipalities in Tuscany were chosen for the sampling according to the peculiarities of their collection systems. In all the SS collection systems investigated, in addition to OFMSW, the fractions collected separately were glass, dry multi-material (polyacrylates, plastic packaging and cans), paper and cardboard and unsorted residue [20,25]. The 5 municipalities had different characteristics in terms of: population density, urban or rural structure, type of collection system implemented (shown in Table 1). The most significant discrimination concerned the choice between the roadside container collection system and the door-to-door system. In the case of road container system (RCS), also called drop-off points, the volume of the container was about $3000 \mathrm{~L}$. Collection points were located at significant distances in order to reduce management costs [26]. The areas might have a range of between 100 and $300 \mathrm{~m}$. There were two RCS examined: the first one in rural area (RDR) and the second one in urban area (RVU), the latter with a peculiarity: a volumetric control with access key is installed on the unsorted residue container to monitor the population regarding the number of undifferentiated injections, in view of the introduction of a specific pay-as-you throw tax [25]. Regarding the door-to-door collection systems (DtDS), three different municipalities were chosen on the basis of 3 peculiarities: the first being a traditional door-to-door collection system in rural area (DDR), the second one in semi-urban area with a pay-as-you-throw charging system (DPS), the third a curbside collection system in urban area (DKU). In the last case deposit points were no longer located at the door, but every $30-50 \mathrm{~m}$ on curbsides. Citizens did 
not have to travel very far and acceptance was good [26]. The systems chosen for this study were representative of the most widespread types of collection in Tuscany.

Table 1. Main characteristics of the studied collection systems.

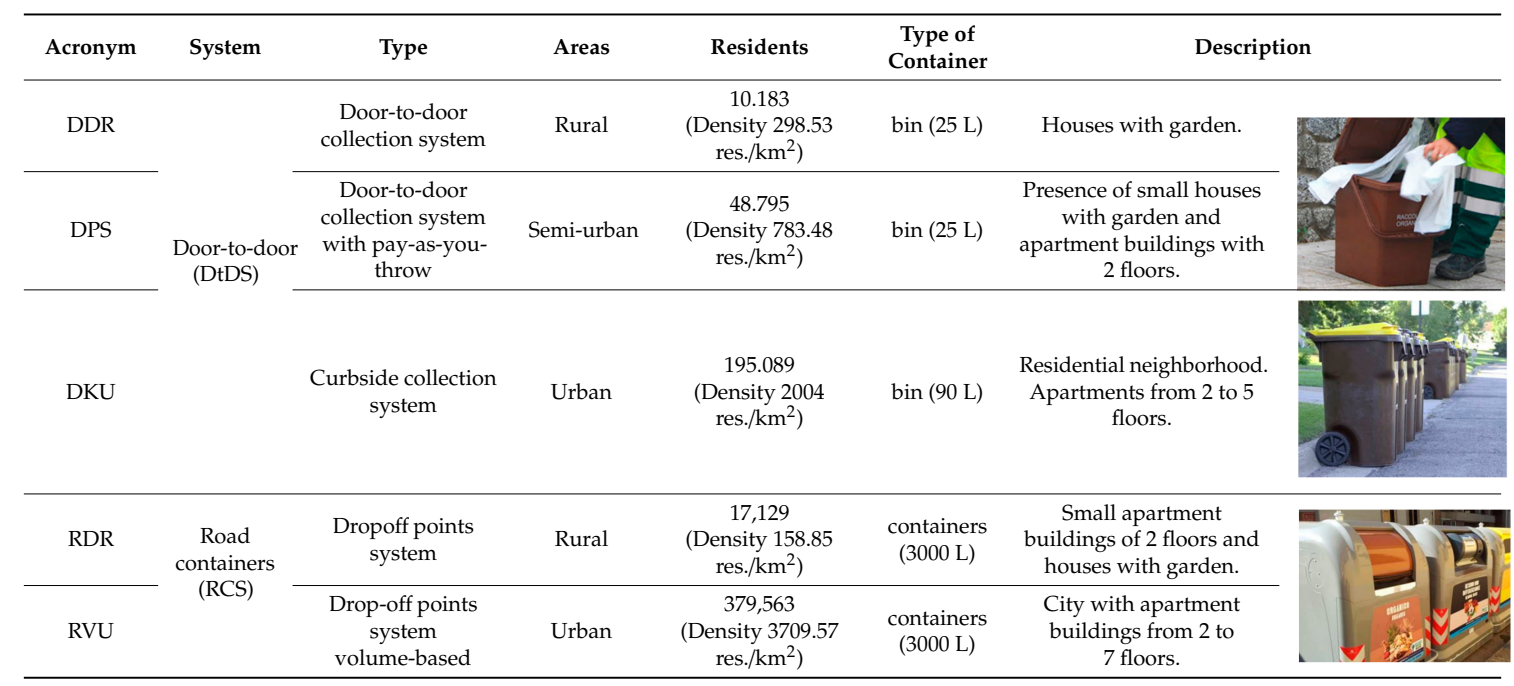

The sampled collection systems were all located in Tuscany where the average monthly maximum and minimum temperatures were as follows: $15.0-4.9^{\circ} \mathrm{C}$ in March, $27.3-14.7^{\circ} \mathrm{C}$ in June, $26.6-14.4^{\circ} \mathrm{C}$ in September, $10.4-2.4^{\circ} \mathrm{C}$ in December. It can be observed that the average temperatures in June and September were comparable.

\subsection{Sampling and Picking Analysis}

The five collection circuits selected were sampled four times, on the first Monday and Tuesday of March, June, September and December, for a total of 20 picking analysis. The 4 months were chosen to represent the 4 different seasons. The choice to consistently sample the same trips (with known vehicle route) and on the same days was made to avoid fairs and weekly markets influencing the result. The analyses were carried out in accordance with POM 346 Rev. 7/2017 [27]. The analysis was performed on OFMSW sample of about $250 \mathrm{~kg}$. The first operation consists in sifting the material through a sieve with an opening of $20 \mathrm{~mm}$, in order to remove the lower fractions and weigh them separately (under sieve). Subsequently, the materials were manually separated, sorted and weighed. The data were returned as a percentage by mass for each individual fraction. The fractions analyzed were: organic matter (kitchen waste), garden waste (both as lignocellulosic cuttings and grass), wood, paper, cardboard, textiles and leather, diapers and sanitary napkins, rigid plastic (packaging), plastic (film), plastic in general, inert materials, metals, glass, rubber, polyacrylates, batteries, pharmaceuticals and finally, under sieve [28].

\subsection{Analysis of Dry and Volatile Matter}

The fractions identified through picking analysis and an undisturbed waste sample (about $10 \mathrm{~kg}$ ) were subsequently analyzed for dry matter content (total solids, TS) and volatile matter content (total volatile solids, TVS). Regarding the organic fractions, garden waste, paper, cardboard and under sieve, 3 separate samples were taken for each pile with the aim of obtaining a more accurate characterization.

The dry matter content was determined by gravimetric procedure as the weight difference found before and after drying the waste at $105^{\circ} \mathrm{C}$ for $24 \mathrm{~h}$ until a constant weight was reached [29]. In addition to the TS content, the volatile matter content was evaluated for each sample. Also in this case the TVS content was estimated through a gravimetric method as the difference in weight found before and after incineration of the sample in muffle at $550{ }^{\circ} \mathrm{C}$ until a constant weight is reached (between 6 and $8 \mathrm{~h}$ ) [30]. Each sample was analyzed in triplicate on aliquots of approximately 100-800 g depending on 
the fraction being analyzed. The above methods were in accordance with the reference standards [31]. In order to calculate the TS and TVS content of the whole waste sample for each type of collection and for each season, two approaches were used: in the first case a whole bag of unaltered waste was taken and dried completely, in the second case all TS and TVS measured on the individual fractions were used to calculate, according to the results of the picking analysis, the weighted average of the solids of the whole sample (calculated from individual sample) [22].

\subsection{Proximate, Ultimate and Bromatological Analysis}

After each picking analysis, a synthetic sample representative of the original OFMSW was reconstructed for the proximate, ultimate and bromatological analysis. Each individual fraction was shredded before being used to compose synthetic samples and to ensure sample homogeneity [32]. In order to reduce the particle size to $3 \mathrm{~mm}$ diameter each fraction was treated in a food processor and sifted with a strainer. Table 2 shows the methods used for proximate, ultimate and bromatological analysis.

Table 2. Methods used for proximate, ultimate and bromatological analysis.

\begin{tabular}{|c|c|c|c|}
\hline Parameter & Method & Parameter & Method \\
\hline $\mathrm{pH}$ & EPA 9045D 2004 & Ammonia & UNI 10780:1998 App. J \\
\hline $\begin{array}{c}\text { Conductivity } \\
\text { Total Organic Carbon (TOC) }\end{array}$ & $\begin{array}{c}\text { APAT CNR IRSA } 2030 \text { Man } 29 \\
2003 \\
\text { UNI 10780:1998 App. E }\end{array}$ & Calcium (Ca); Aluminum (Al) & $\begin{array}{c}\text { UNI EN 13657:2004 + UNI EN ISO } \\
11885: 2009\end{array}$ \\
\hline C/N ratio & UNI EN 13137:2002 + UNI EN & $\begin{array}{l}\text { Phosphorus (P) } \\
\text { Sodium (Na) }\end{array}$ & EPA 3050B 1996 + EPA 6010D 2014 \\
\hline Hydrogen $(\mathrm{H})$ & $\begin{array}{c}\text { 15407:2011 } \\
\text { DM 13/09/1999 SO GU n } 248 \\
\text { 21/10/1999 Met VII.1 }\end{array}$ & $\begin{array}{l}\text { Potassium }(\mathrm{K}) \\
\quad \text { Iron }(\mathrm{Fe}) \\
\text { Magnesium }(\mathrm{Mg})\end{array}$ & $\begin{array}{c}\text { UNI 10780:1998 App. B } \\
\text { EPA 3050B 1996 + EPA 6010D } 2014 \\
\text { UNI EN 13657:2004 + UNI EN ISO } \\
\text { 11885:2009 }\end{array}$ \\
\hline Carbon (C) & DM 13/09/1999 SO GU n ${ }^{\circ} 248$ & Manganese (Mn) & $\begin{array}{c}\text { UNI EN 13657:2004 + UNI EN ISO } \\
11885: 2009\end{array}$ \\
\hline Nitrogen $(\mathrm{N})$ & $\begin{array}{l}\text { 21/10/1999 Met VII.3 } \\
\text { UNI EN 15407:2011 }\end{array}$ & Molybdenum (Mo) & $\begin{array}{c}\text { UNI EN 13657:2004 + UNI EN ISO } \\
11885: 2009\end{array}$ \\
\hline Sulphur (S) & EPA 50501994 + EPA $9056^{\circ} 2007$ & Nickel (Ni) & UNI 10780:1998 App. B \\
\hline $\begin{array}{l}\text { Lignin, Cellulose, Hemicellulose, } \\
\text { Carbohydrates }\end{array}$ & POM 017 Rev. 02011 & $\begin{array}{c}\text { Lead }(\mathrm{Pb}) \\
\text { Mercury }(\mathrm{Hg})\end{array}$ & UNI 10780:1998 App. B \\
\hline Protein & ISTISAN 1996/34 pag.13 & Copper $(\mathrm{Cu})$ & UNI 10780:1998 App. B \\
\hline Lipids & CNR IRSA Met 21 Q 64 vol 31998 & Arsenic (As) & UNI 10780:1998 App. B \\
\hline
\end{tabular}

\subsection{Biochemical Methane Potential (BMP) Test}

For each reconstituted synthetic sample, the BMP test was carried out in order to estimate the biochemical energy potential as feedstock in an AD plant [33]. The BMP tests were performed following the guidelines of Angelidaki et al. (2009) [34] and the measurement protocol described by Pecorini et al. (2019) [35]. The test was conducted using stainless steel bottles (1 L volume, 2 bar proof) designed by Pecorini et al. [32,36], incubated in a hot bath at $37^{\circ} \mathrm{C}$ (mesophilic conditions) and firmly closed by a steel cap fitted with an opening valve to allow gas sampling. The tests were conducted in triplicate and were expressed in cumulative production of $\mathrm{CH}_{4}$ in terms of $1 \mathrm{~kg}$ of total volatile solids $\left(\mathrm{NLCH}_{4}\right.$ $\mathrm{kg}_{\mathrm{TVS}^{-1}}{ }^{-1}$. Cumulative biogas production, called in this work Gas generation Sum (GS) was expressed in $\mathrm{Nm}^{3} \mathrm{t}_{\mathrm{OFMSW}}{ }^{-1}$ (considering $1 \mathrm{t}$ of raw OFMSW) [37]. The biogas produced was then analyzed in the methane content with infrared gas analyzer (ECOPROBE 5, RS Dynamics, Czech Republic) or a micro-gas chromatograph (INFICON, Switzerland) in the case of residual production [38]. The tests were performed over a period of 40 days.

\subsection{Statistical Analysis}

In order to evaluate differences between dry matter and energy potential of OFMSW from different collection systems, in terms of BMP, an analysis of variance (ANOVA) test and Tukey's test in pairwise comparison were performed using XLStat2018 software (Addinsoft, New York, US), assuming a confidence level of $95 \%[4,32,38]$. 


\section{Results and Discussion}

\subsection{Picking Analysis}

\subsubsection{Variability due to Collection System}

The results of the picking analysis carried out on the 5 collection systems are shown in Appendix A, Table A1. It was possible to observe how on average the components most present were kitchen waste $(55 \% \pm 9 \%)$ and garden waste (both lignocellulosic and grass components, respectively $16 \% \pm 1 \%$ and $5 \% \pm 1 \%$ ). The sum of non-compostable fractions (sum of cardboard, plastic, rubber, glass, diapers, wood, textiles, inert, metals, batteries, drugs and insertion errors) was on average equal to $14 \% \pm 12 \%$. Paper and cardboard were on average $5 \% \pm 0.4 \%$ and under sieve $6 \% \pm 2 \%$. In general, undesirable OFMSW fractions were more present in RCS.

In general, the collection circuit with the lowest percentage of kitchen waste was RDR (42\% $\pm 8 \%$ ) which, at the same time, has a greater percentage of garden waste $(30 \% \pm 25 \%)$ than the other circuits. Conversely, the highest contribution of kitchen waste was found for DPS $(66 \% \pm 6 \%)$ with a garden waste contribution of $10 \% \pm 9 \%$. Comparing DtDS and RCS, it was possible to observe that the quality in terms of purity of the first system was higher than the second. In fact, the sum of the non-compostable fractions in DtDS was equal to about $6 \% \pm 1 \%$ while for RCS it was equal to $22 \% \pm 1 \%$ (Figure 1). The last result is comparable with what was presented by Cesaro et al. [39], who estimated a composition of OFMSW with a value of plastic and undesirable aggregates close to $12 \%$. Also Alvarez et al. [40] showed that, in Catalonia, separately collected biowaste contained between $10 \%$ and $20 \%$ of undesirable material.
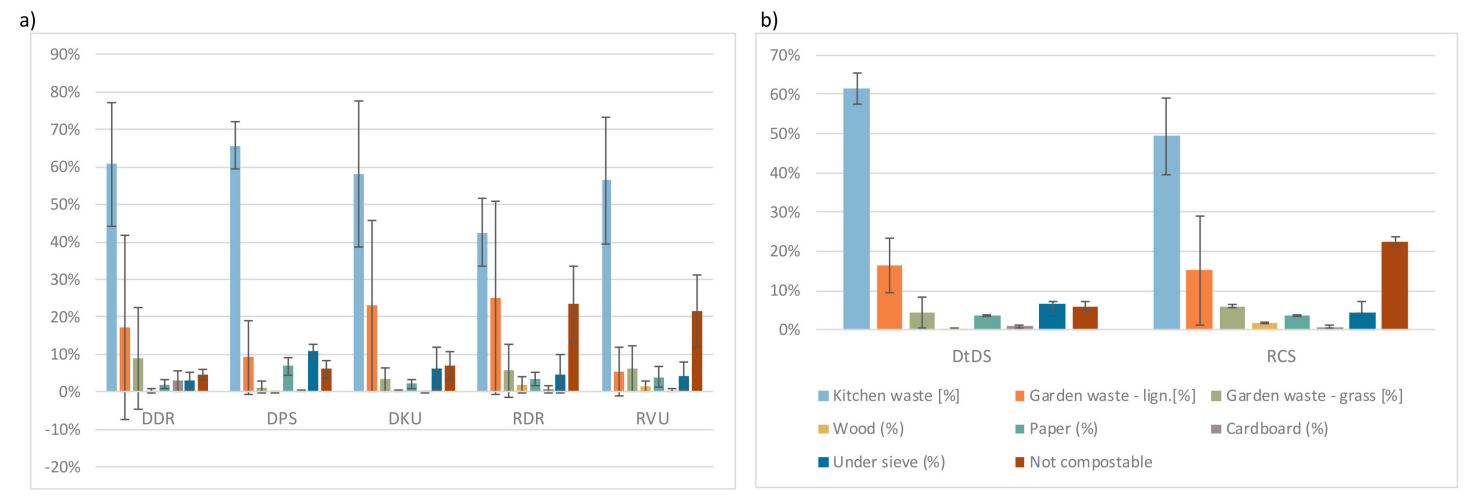

Figure 1. Picking analysis results for each of the 5 collection systems studied (a) and in aggregate form for DtDS and RCS (b). Averages are expressed as weight/weight percentage. Error bars represent standard deviation.

\subsubsection{Seasonal Variability}

Table A2, in Appendix A, shows the results of the seasonal variability of the collection systems sampled in March, June, September and December. It can be observed that the trend of the green fraction was strongly linked to seasonality, which determined the number of cuttings and pruning and therefore the increase (in June) or decrease (in December) of garden waste. The result affects the percentage of kitchen waste, which was visibly higher in December $(67.57 \% \pm 7.58 \%)$ and lower in June $(44.84 \% \pm 9.67 \%)$. The paper fraction seems to have a similar trend to kitchen waste, presumably related to the fact that paper napkins are often thrown away together with food waste. The sum of the non-compostable fractions did not seem to follow the trend of the main fractions: kitchen waste and garden waste.

As far as the composition of the garden waste was concerned (Figure 2), it was observed that the percentage of lignocellulosic waste was greater in June $(42.33 \% \pm 14.15 \%)$ while the waste due to grass cutting was more present in December $(10.51 \% \pm 9.61 \%)$. It was observed that in the months with 
higher temperature (June and September) pruning greatly influenced (and reduced) the percentage of the kitchen waste and was clearly prevailing compared to the other fractions in the months with lower temperature (March and December).

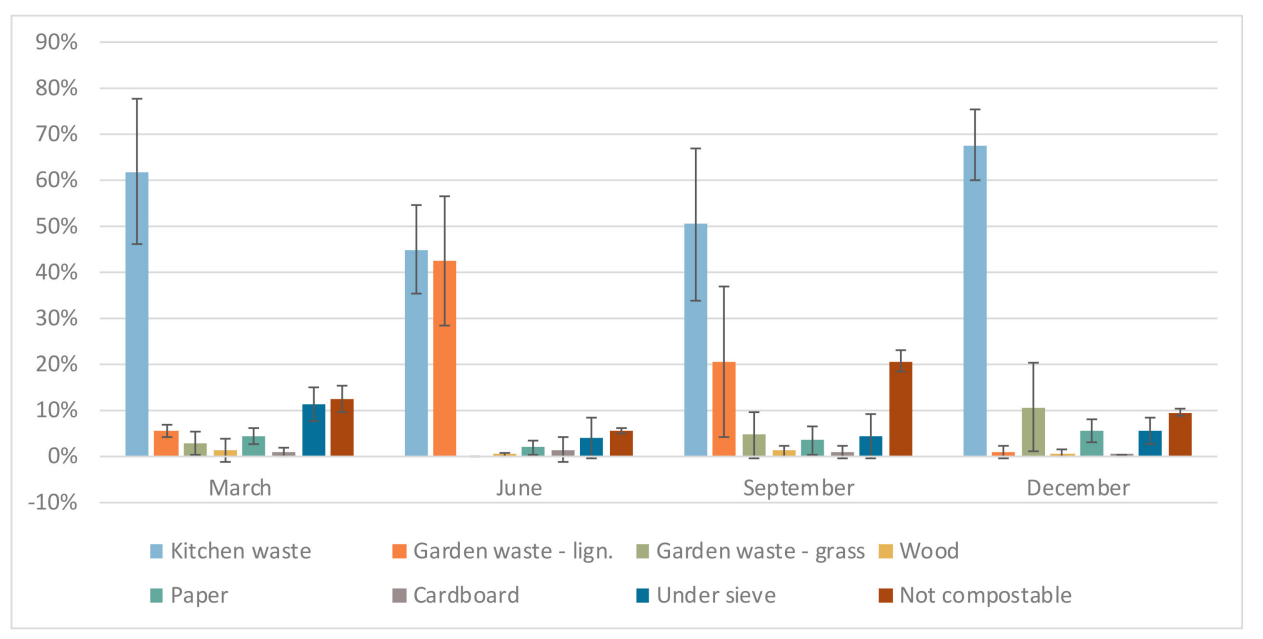

Figure 2. Picking analysis results for each studied season. Averages are expressed as weight/weight percentage. Error bars represent standard deviation.

\subsection{Dry and Volatile Matter}

Table 3 shows the percentage values of TS and TVS (expressed with TSV/TS) for each collection system and for each season studied. The solids were determined in two ways: the first, by drying an undisturbed sample of waste of about $10 \mathrm{~kg}$; the second, starting from the solids from the individual fractions separated in the picking analysis (calculated from individual sample). The two methods led to similar results and by analyzing the results with one-way ANOVA the populations were not statistically different ( $p$ value was equal to 0.37 for TS and 0.48 for TVS both higher than 0.05 ). In general, the TS of the sampled OFMSW were about $42 \%$ while the TVS ranged between $83.3 \%$ and $81.9 \%$. These values are fairly comparable with Campuzano and González-Martínez [13] who studied the composition of OFMWS in 11 countries around the world and obtained an average TS of $27.2 \% \pm 7.6 \%$ and an average TVS of $84.6 \% \pm 9.9 \%$. López et al. [41] studies OFMSW from 4 different countries and finds that the dry matter content is approximately $30.9 \% \pm 6.6 \%$. It can be observed that in terms of dry matter the samples studied were slightly drier than those found in previous works perhaps due to the presence of garden waste and undesirable substances (such as non-compostable fractions with high TS content).

The collection systems in rural areas (DDR, RDR) had a higher solids content than those in urban (DKU, RVU) and semi-urban (DPS) areas. In fact, the TS in rural areas were $43.9 \% \pm 2 \%$ while in urban and semi-urban areas $40.6 \% \pm 2.1 \%$. Considering the average TS values obtained with the two approaches, it appears that the seasonal variation between March, June, September and December was respectively: $43.8 \% \pm 1.5 \% ; 41.3 \% \pm 1.7 \% ; 41.5 \% \pm 1.0 \%$ and $44.2 \% \pm 5.3 \%$. The data showed a linear correlation between average Tuscan temperatures and seasonal mean TS obtained from this study $\left(R^{2}=0.982\right)$. Regarding TVS, on the other hand, no trend was observed.

The TS of the individual fractions obtained from picking analysis are shown in Figure 3. No trends were observed depending on the collection systems. On average the TS of kitchen waste was $39 \% \pm 3 \%$ while the TS of garden waste was $37 \% \pm 11 \%$ for grass waste and $47 \% \pm 7 \%$ for ligno-cellulosic waste due to pruning. The TS of the driest fractions such as paper and plastic were $46 \% \pm 10 \%$ and $50 \% \pm 5 \%$ respectively. While the under sieve had a dry matter content of $54 \% \pm 6 \%$.

In terms of volatile matter, no trend depending on the collection system was present, as shown in Figure 4. On average the TVS of kitchen waste was $82 \% \pm 2 \%$ while the TS of garden waste was $75 \% \pm 4 \%$ for grass waste and $86 \% \pm 2 \%$ for ligno-cellulosic waste due to pruning. The TS of paper 
and plastic were $93 \% \pm 2 \%$ and $88 \% \pm 2 \%$ respectively, while the under sieve had a dry matter content of $58 \% \pm 12 \%$.

Table 3. Dry and volatile matter result for different collection systems $(n=4)$ and season $(n=5)$. Averages and standard deviation are expressed as weight/weight percentages.

\begin{tabular}{|c|c|c|c|c|c|c|c|c|}
\hline \multirow[t]{2}{*}{ ID } & \multicolumn{2}{|c|}{ TS (\%) } & \multicolumn{2}{|c|}{$\begin{array}{l}\text { TS (\%)_Calculated from } \\
\text { Individual Sample }\end{array}$} & \multicolumn{2}{|c|}{ TVS/TS (\%) } & \multicolumn{2}{|c|}{$\begin{array}{l}\text { TVS/TS (\%)-Calculated } \\
\text { from Individual Sample }\end{array}$} \\
\hline & Mean & st.d. & mean & st.d. & mean & st.d. & mean & st.d. \\
\hline $\mathrm{DDR}^{*}$ & $41.2 \%$ & $10.0 \%$ & $40.1 \%$ & $2.3 \%$ & $87.2 \%$ & $2.0 \%$ & $82.6 \%$ & $6.3 \%$ \\
\hline DKU* & $43.5 \%$ & $6.4 \%$ & $43.6 \%$ & $2.6 \%$ & $85.6 \%$ & $6.7 \%$ & $82.6 \%$ & $4.9 \%$ \\
\hline DPS* & $47.7 \%$ & $9.7 \%$ & $41.4 \%$ & $7.3 \%$ & $81.5 \%$ & $7.5 \%$ & $80.3 \%$ & $4.3 \%$ \\
\hline $\mathrm{RDR}^{*}$ & $38.1 \%$ & $5.4 \%$ & $42.9 \%$ & $4.7 \%$ & $72.5 \%$ & $20.1 \%$ & $82.9 \%$ & $8.5 \%$ \\
\hline $\mathrm{RVU}^{*}$ & $44.3 \%$ & $6.6 \%$ & $42.6 \%$ & $6.3 \%$ & $92.4 \%$ & $3.0 \%$ & $74.4 \%$ & $6.1 \%$ \\
\hline March $^{* *}$ & $42.8 \%$ & $0.2 \%$ & $44.8 \%$ & $1.8 \%$ & $88.6 \%$ & $7.3 \%$ & $79.3 \%$ & $7.8 \%$ \\
\hline June $e^{* *}$ & $40.1 \%$ & $7.4 \%$ & $42.5 \%$ & $6.1 \%$ & $72.3 \%$ & $16.7 \%$ & $86.2 \%$ & $3.9 \%$ \\
\hline September** & $40.8 \%$ & $4.9 \%$ & $42.2 \%$ & $2.4 \%$ & $83.5 \%$ & $2.5 \%$ & $82.8 \%$ & $5.6 \%$ \\
\hline December** & $48.0 \%$ & $12.2 \%$ & $40.5 \%$ & $6.3 \%$ & $88.6 \%$ & $3.5 \%$ & $79.3 \%$ & $7.8 \%$ \\
\hline $\begin{array}{l}\text { Annual } \\
\text { average }\end{array}$ & $42.9 \%$ & $3.6 \%$ & $42.5 \%$ & $1.8 \%$ & $83.3 \%$ & $7.7 \%$ & $81.9 \%$ & $3.3 \%$ \\
\hline
\end{tabular}

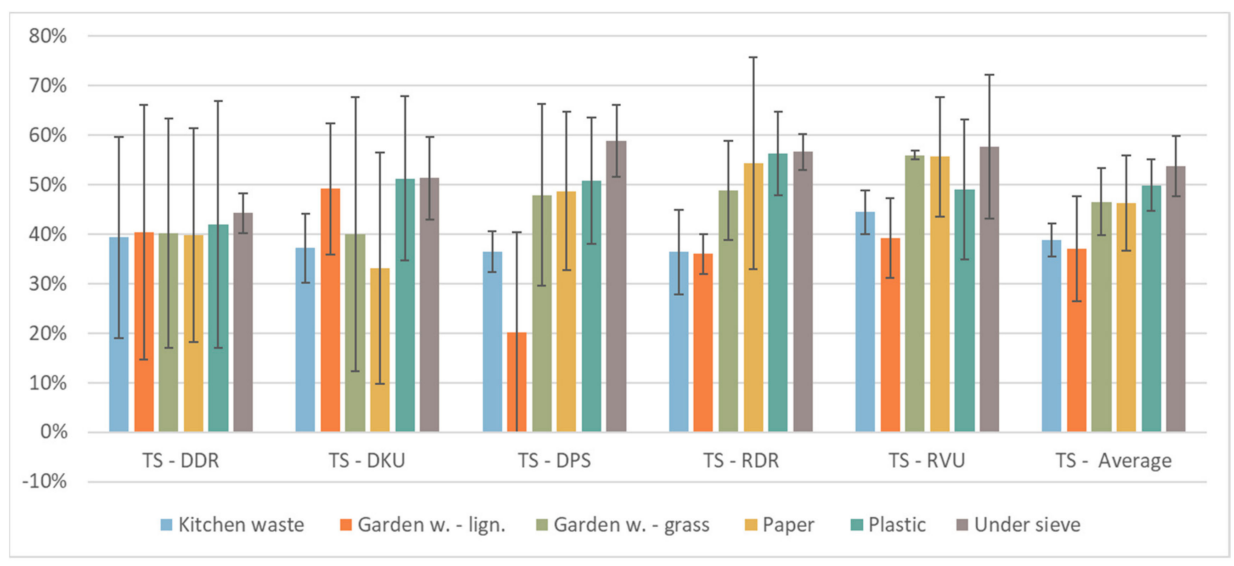

Figure 3. Dry matter of the fractions obtained from picking analysis results for each collection system studied $(n=4)$. Averages are expressed as weight/weight percentage. Error bars represent standard deviation.

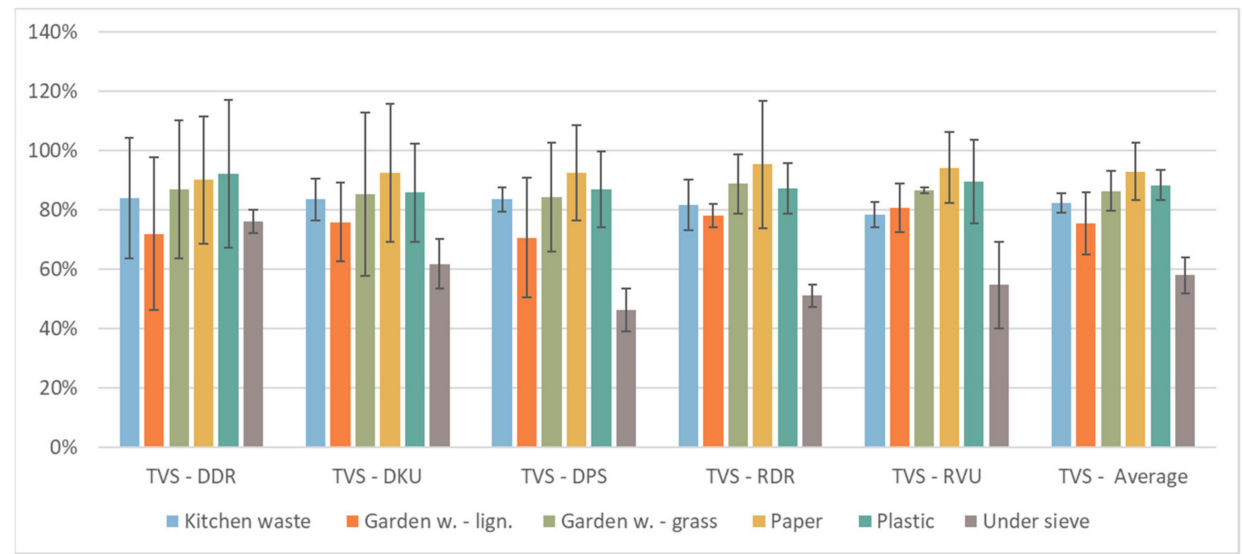

Figure 4. Volatile matter of fractions obtained in picking analysis results for each collection system studied $(n=4)$. Averages are expressed as weight/weight percentage. Error bars represent standard deviation. 


\subsection{Proximate, Ultimate and Bromatological Analysis}

\subsubsection{Variability due to Collection Systems}

Table 4 shows the results of the proximate, ultimate and bromatological characterization of the mashes obtained by reconstituting the sample with the individual shredded fractions, according to the composition provided by the picking analysis for different collection systems. In Table 4, the values of TS and TVS refer to mash. Regarding the proximate analysis, the average $\mathrm{pH}$ value obtained was $4.51 \pm 0.03$, comparable with other authors' findings on the OFMSW of 11 countries, equal to $5.2 \pm 0.95$ [13]. Compared to total organic carbon (TOC) for DtDS, it was $23.5 \% \pm 3.9 \%$, as opposed to $27.2 \% \pm 2.8 \%$ similar to RCS. In general, observing the bromatological analysis, the values obtained for the CHNS composition were similar among the different types of collection and comparable to those obtained by previous authors $[7,13,18]$. In particular, the average composition obtained from this study was $44.1 \pm 2.1 \% \mathrm{TS}$ of $\mathrm{C}, 6.2 \pm 1.8 \% \mathrm{TS}$ of $\mathrm{H}, 2.1 \pm 0.03 \% \mathrm{TS}$ of $\mathrm{N}$ and finally $0.16 \pm 0.16 \% \mathrm{TS}$ of $\mathrm{S}$. The last composition is comparable to the findings of Campuzano and González-Martínez [13] roughly corresponding to $46.6 \pm 4.4 \% \mathrm{TS}$ of $\mathrm{C}, 6.6 \pm 0.6 \% \mathrm{TS}$ of $\mathrm{H}, 2.9 \pm 0.6 \% \mathrm{TS}$ of $\mathrm{N}$ and finally $0.3 \pm 0.26 \% \mathrm{TS}$ of $\mathrm{S}$.

Compounds that can inhibit the normal course of the methanization process include sulfides [42], regarding which, there are two types of inhibitory causes of the process. The first is due to competition between sulphate-reducing bacteria and methanogenic bacteria for the use of organic matter, the second is due to the toxicity of sulfides for the various bacterial groups. The formation of hydrogen sulfide in anaerobic reactors is the result of the reduction of oxidized sulfur compounds and the dissimilation of sulfur-based amino acids (e.g., cysteine). Methanogenic bacteria can tolerate concentrations of hydrogen sulfide up to $1000 \mathrm{mgkg}^{-1}$ of total solid. The only parameter studied to indicate the presence of sulfur in substrates is the concentration of sulfur itself which always has minimal and insignificant content [42].

As for the $\mathrm{C} / \mathrm{N}$ ratio, the optimal value for the AD process is between 20-30 [43]. Values above 30 can be a source of process instability due to insufficient nutrients influencing bacterial activity and, consequently, substrate consumption and methane production. At the same time, values below 6 negatively affect the process due to low carbon availability and, generally, high concentration of ammoniacal nitrogen. López et al. [41] studies the $\mathrm{C} / \mathrm{N}$ ratio in different samples of OFMSW from 4 different countries and confirms that the average value is $17 \pm 1.5$. As can be seen from Table 4 , most of the parameters fall within the range of the literature [21,43].

Regarding bromatological analyses, it is observed that carbohydrates were the predominant component followed by lignin and cellulose. Analyzing the urban and semi-urban collection systems separately from the rural ones, it emerged that in the former, the content of carbohydrates, lignin and cellulose was about $44.2 \pm 2.5 \% \mathrm{TVS}, 18.1 \pm 5.2 \% \mathrm{TVS}, 19 \pm 1.2 \% \mathrm{TVS}$; in the latter $39.8 \pm 3.4 \% \mathrm{TVS}$, $26.2 \pm 6.1 \% \mathrm{TVS}, 19.9 \pm 1.9 \%$ TVS respectively. Lignin was more present in rural circuits consistently with the increased presence of pruning, while carbohydrates, the main constituent of kitchen waste, were more present in urban circuits. Similar considerations can be made for the differences between DtDS and RCS, where the carbohydrate, lignin and cellulose contents were respectively: $41 \pm 3.2 \%$ TVS, $24 \pm 6.1 \%$ TVS, $18.9 \pm 1.2 \%$ TVS for DtDS and $44.6 \pm 3.3 \%$ TVS, $17.2 \pm 6.5 \%$ TVS, $20.2 \pm 1.5 \%$ TVS for RCS, as shown in Figure 5. The average results of the bromatological composition are comparable to studies performed by other authors $[7,13,18]$. In particular, in a study on OFMWS from 11 countries, Campuzano and González-Martínez [13], find that the mean bromatological composition is as follows: $15.5 \pm 66.6 \%$ TVS of oils and fats, $17.7 \pm 5.5 \%$ TVS of proteins, $9.7 \pm 5.3 \%$ TVS of lignin, $18.6 \pm 15 \%$ TVS of cellulose, $8.6 \pm 4.6 \%$ TVS of hemicellulose and $27.6 \pm 12 \%$ TVS of carbohydrates. Therefore, it is confirmed that carbohydrates are the predominant component. 
Table 4. Proximate, ultimate and bromatological analyses for different collection systems $(n=4)$.

\begin{tabular}{|c|c|c|c|c|c|c|c|c|c|c|c|}
\hline \multirow[t]{2}{*}{ Analysis } & \multirow[b]{2}{*}{ Unit } & \multicolumn{2}{|c|}{ DDR } & \multicolumn{2}{|c|}{ DKU } & \multicolumn{2}{|c|}{ DPS } & \multicolumn{2}{|c|}{ RDR } & \multicolumn{2}{|c|}{ RVU } \\
\hline & & Mean & St. Dev. & Mean & St. Dev. & Mean & St. Dev. & Mean & St. Dev. & Mean & St. Dev. \\
\hline \multicolumn{12}{|l|}{ Proximate } \\
\hline $\mathrm{pH}$ & - & 4.33 & 0.78 & 4.39 & 0.72 & 4.62 & 0.62 & 5.04 & 0.74 & 3.93 & 0.11 \\
\hline Conductivity & $\mu \mathrm{S} / \mathrm{cm}$ & 4120.88 & 1346.83 & 3681.55 & 2513.19 & 5308.10 & 908.79 & 4745.54 & 811.27 & 5025.00 & 657.61 \\
\hline Ash & $\%$ & 6.64 & 4.44 & 63.99 & 115.38 & 6.41 & 2.34 & 7.23 & 3.76 & 3.66 & 0.49 \\
\hline TS & $\%$ & 30.57 & 8.77 & 31.35 & 18.34 & 31.98 & 5.74 & 40.18 & 12.58 & 31.00 & 11.03 \\
\hline TVS & $\%$ & 23.93 & 4.35 & 32.50 & 5.55 & 25.56 & 5.56 & 32.95 & 12.16 & 27.35 & 10.54 \\
\hline TOC & $\%$ & 20.21 & 4.61 & 27.92 & 2.84 & 22.46 & 4.36 & 29.21 & 11.75 & 25.20 & 9.48 \\
\hline \multicolumn{12}{|l|}{ Ultimate } \\
\hline $\mathrm{C}$ & $\%$ TS & 43.06 & 6.55 & 43.75 & 5.26 & 42.65 & 2.43 & 44.63 & 4.98 & 47.80 & 2.38 \\
\hline $\mathrm{H}$ & $\%$ TS & 5.98 & 1.25 & 15.38 & 18.36 & 6.07 & 0.48 & 6.32 & 0.88 & 6.63 & 0.11 \\
\hline $\mathrm{N}$ & $\%$ TS & 2.16 & 0.47 & 3.03 & 2.04 & 2.07 & 0.26 & 2.21 & 0.51 & 2.54 & 0.31 \\
\hline$S$ & $\% \mathrm{TS}$ & 0.17 & 0.10 & 0.72 & 1.10 & 0.18 & 0.11 & 0.14 & 0.07 & 0.14 & 0.06 \\
\hline $\mathrm{C} / \mathrm{N}$ & & 23.12 & 2.79 & 15.46 & 10.26 & 22.43 & 4.59 & 24.83 & 6.12 & 19.00 & 2.83 \\
\hline \multicolumn{12}{|l|}{ Bromatological } \\
\hline Lignin & $\%$ TVS & 30.58 & 13.91 & 18.45 & 8.52 & 23.21 & 15.21 & 21.87 & 12.19 & 12.64 & 2.03 \\
\hline Cellulose & $\%$ TVS & 18.55 & 6.09 & 17.88 & 7.28 & 20.31 & 4.40 & 21.32 & 5.61 & 19.07 & 7.87 \\
\hline Hemicellulose & $\%$ TVS & 2.63 & 2.61 & 3.55 & 2.86 & 1.87 & 1.16 & 2.33 & 1.38 & 1.60 & 0.57 \\
\hline Carbohydrates & $\%$ TVS & 37.36 & 22.90 & 43.57 & 24.32 & 42.10 & 19.10 & 42.28 & 20.49 & 46.98 & 12.40 \\
\hline Protein & $\%$ TVS & 15.97 & 0.82 & 23.54 & 19.84 & 15.10 & 1.08 & 14.56 & 2.79 & 14.58 & 2.14 \\
\hline Lipids & $\%$ TVS & 1.41 & 0.97 & 3.58 & 6.11 & 1.07 & 0.73 & 0.82 & 0.62 & 1.15 & 0.57 \\
\hline
\end{tabular}



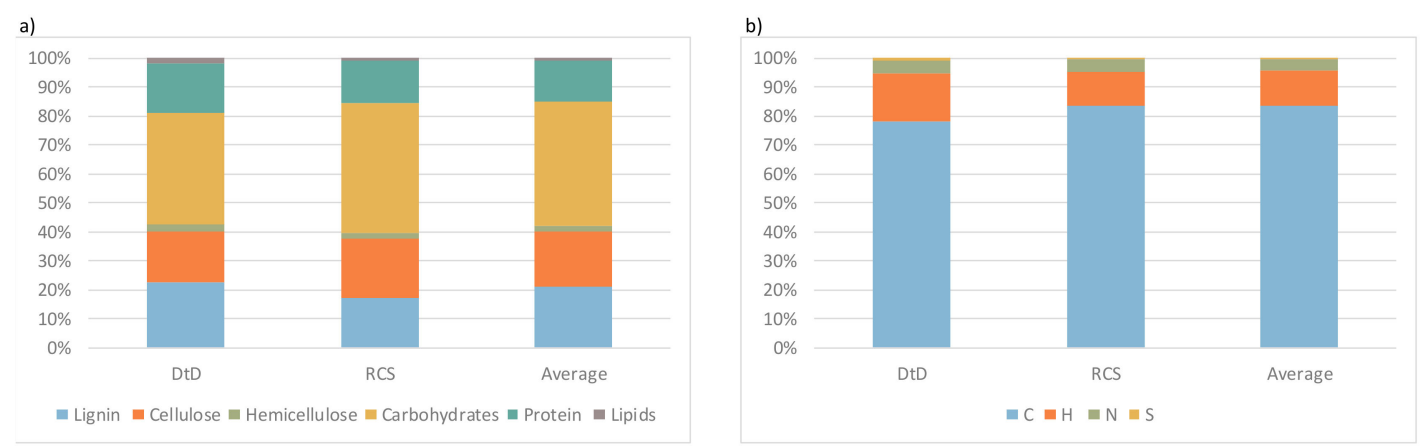

Figure 5. Ultimate (a) and bromatological (b) analyses for different collection systems (DtDS and RCS).

\subsubsection{Seasonal Variability}

Regarding the influence of the seasons on the results of the proximate and ultimate analysis, there was a weak correlation between the parameters analyzed and the indicators detected (Table 5). The $\mathrm{pH}$ in the warmer months was $4.87 \pm 0.48$ and comparable to the $\mathrm{pH}$ in the colder months when it was $4.16 \pm 0.34$. The ash content in the warmer months was $7.03 \% \pm 4.36 \%$, which was higher than in the colder months when it was $5.38 \% \pm 0.08 \%$, probably influenced by the garden waste content.

With regard to the elementary composition CHNS, no variations were observed; in fact, in the hotter months this was $45.3 \pm 4.9 \% \mathrm{TS}$ of $\mathrm{C}, 6.4 \pm 0.6 \% \mathrm{TS}$ of $\mathrm{H}, 2.2 \pm 0.13 \% \mathrm{TS}$ of $\mathrm{N}$ and finally $0.22 \pm 0.10 \% \mathrm{TS}$ of $\mathrm{S}$ while in the colder months it was $43.0 \pm 2.8 \% \mathrm{TS}$ of $\mathrm{C}, 6.0 \pm 0.6 \% \mathrm{TS}$ of $\mathrm{H}, 2.1 \pm 0.16$ $\% \mathrm{TS}$ of $\mathrm{N}$ and finally $0.11 \pm 0.01 \% \mathrm{TS}$ of S.

The results of the bromatological analysis were influenced by seasonality; in fact, the percentages of lignin and carbohydrates varied depending on the month of sampling (Figure 6). The prevalent components were the carbohydrates, lignin and cellulose equal to, respectively, $40.2 \pm 9.1 \% \mathrm{TVS}$, $30.7 \pm 11 \%$ TVS, $23.5 \pm 0.2 \%$ TVS in the warmer months and $49.0 \pm 11 \%$ TVS, $13.7 \pm 5.6 \%$ TVS, $15.2 \pm 2.71 \%$ TVS in the colder months. A significant contribution of $15.17 \pm 0.05 \%$ TVS was also observed for the protein in the warm months and $14.2 \pm 0.1 \%$ TVS in the cold months. In the warm months, the contribution of garden waste reduces the carbohydrate content in favor of lignin. A low lipid content was also observed compared to that found by other authors $[11,18,20]$, probably due to the fact that many authors study food waste (and therefore kitchen waste alone) while in this study OFMSW was studied in its entirety including garden, paper and undesirable waste fractions.

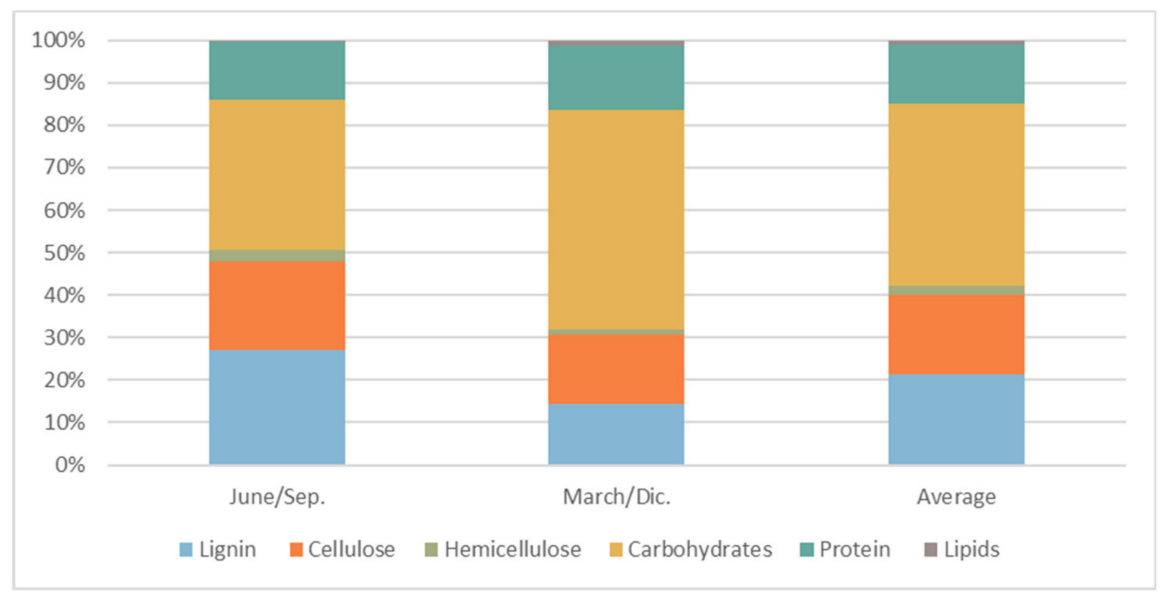

Figure 6. Bromatological analysis for different seasons. Average is expressed as \%TVS/TS. 
Table 5. Proximate, ultimate and bromatological analyses for different seasons $(n=5)$.

\begin{tabular}{|c|c|c|c|c|c|c|c|c|c|c|c|}
\hline \multirow[t]{2}{*}{ Analysis } & \multirow[b]{2}{*}{ Unit } & \multicolumn{2}{|c|}{ March } & \multicolumn{2}{|c|}{ June } & \multicolumn{2}{|c|}{ September } & \multicolumn{2}{|c|}{ December } & \multicolumn{2}{|c|}{ Average } \\
\hline & & Mean & St. Dev. & Mean & St. Dev. & Mean & St. Dev. & Mean & St. Dev. & Media & St. Dev. \\
\hline \multicolumn{12}{|l|}{ Proximate } \\
\hline $\mathrm{pH}$ & - & 3.91 & 0.07 & 5.21 & 0.01 & 4.53 & 0.74 & 4.40 & 0.74 & 4.51 & 0.54 \\
\hline Conductivity & $/ \mathrm{cm}$ & 5197.50 & 310.20 & 5752.35 & 485.73 & 3775.00 & 606.88 & 4658.00 & 576.47 & 4845.71 & 842.10 \\
\hline Ash & $\%$ & 5.33 & 2.22 & 10.11 & 0.61 & 3.95 & 2.70 & 5.43 & 2.23 & 6.21 & 2.69 \\
\hline TS & $\%$ & 43.93 & 9.22 & 37.76 & 1.66 & 32.00 & 9.06 & 27.30 & 3.44 & 35.25 & 7.20 \\
\hline TVS & $\%$ & 38.60 & 7.15 & 27.65 & 1.05 & 28.05 & 8.92 & 21.87 & 2.09 & 29.04 & 6.97 \\
\hline TOC & $\%$ & 34.40 & 7.85 & 24.47 & 0.94 & 22.78 & 5.89 & 19.12 & 1.14 & 25.19 & 6.53 \\
\hline \multicolumn{12}{|l|}{ Ultimate } \\
\hline $\mathrm{C}$ & $\% \mathrm{TS}$ & 45.07 & 3.20 & 48.87 & 1.90 & 41.83 & 2.42 & 41.00 & 3.82 & 44.19 & 3.58 \\
\hline $\mathrm{H}$ & $\% \mathrm{TS}$ & 6.45 & 0.25 & 6.97 & 0.20 & 5.99 & 0.54 & 5.56 & 0.77 & 6.24 & 0.60 \\
\hline $\mathrm{N}$ & $\%$ TS & 2.01 & 0.35 & 2.33 & 0.02 & 2.15 & 0.60 & 2.24 & 0.41 & 2.18 & 0.14 \\
\hline $\mathrm{S}$ & $\% \mathrm{TS}$ & 0.10 & 0.02 & 0.28 & 0.05 & 0.15 & 0.02 & 0.11 & 0.04 & 0.16 & 0.08 \\
\hline $\mathrm{C} / \mathrm{N}$ & & 25.00 & 4.03 & 20.92 & 0.55 & 26.63 & 4.37 & 18.60 & 1.95 & 22.79 & 3.68 \\
\hline \multicolumn{12}{|l|}{ Bromatological } \\
\hline Lignin & \%TVS/TS & 9.73 & 2.08 & 22.47 & 2.26 & 38.98 & 9.44 & 17.67 & 3.33 & 22.21 & 12.35 \\
\hline Cellulose & \%TVS/TS & 13.38 & 4.34 & 23.45 & 0.68 & 23.56 & 3.72 & 17.21 & 4.67 & 19.40 & 4.99 \\
\hline Hemicellulose & $\% \mathrm{TVS} / \mathrm{TS}$ & 1.70 & 0.53 & 2.13 & 0.54 & 3.95 & 1.38 & 0.74 & 0.68 & 2.13 & 1.35 \\
\hline Carbohydrates & $\%$ TVS/TS & 57.11 & 7.33 & 60.79 & 0.01 & 19.60 & 7.58 & 41.04 & 7.37 & 44.63 & 18.76 \\
\hline Protein & $\%$ TVS/TS & 14.15 & 2.11 & 15.21 & 0.59 & 15.13 & 3.32 & 14.31 & 1.54 & 14.70 & 0.55 \\
\hline Lipids & \%TVS/TS & 0.76 & 0.44 & 0.55 & 0.08 & 0.68 & 0.41 & 1.98 & 0.36 & 0.99 & 0.67 \\
\hline
\end{tabular}




\subsubsection{Nutritional Elements and Metals}

Compounds that can inhibit the normal course of the methanization process include ammoniacal nitrogen, heavy metals and light metals [42].

Ammonia may be present directly in the substrate or formed in the AD process by biological degradation of nitrogen substances, mainly proteins [42]. According to APAT, 2005 [44] concentrations lower than $1500 \mathrm{mg} / \mathrm{kg}$ of ammonia do not have adverse effects on the formation of methane while, exceeding $1500 \mathrm{mg} / \mathrm{kg}$, the behavior of the system can be different depending on the adaptation or not of the biomass; in general it has been observed that concentrations of ammoniacal nitrogen between 1500 and $3000 \mathrm{mg} / \mathrm{kg}$ are inhibitory at $\mathrm{pH}$ lower than 7.5 while concentrations higher than $3000 \mathrm{mg} / \mathrm{L}$ are toxic at any $\mathrm{pH}$ value. The ammonia concentration found (Tables $\mathrm{A} 3$ and $\mathrm{A} 4$ ) were below the inhibitory limit.

Sodium, potassium, calcium, magnesium and aluminum are often present in DA input substrates. Like other nutrients, potassium and calcium are necessary for bacterial growth but excessive concentrations may limit it or cause inhibition of the process. For heavy metals the elements of interest are chromium, iron, copper, zinc and cadmium. Unlike other toxic substances, heavy metals are not biodegradable and can accumulate in potentially toxic concentrations. The toxicity of metal ions occurs because they inactivate many enzymes by interacting with their sulfhydryl groups. The toxicity limits for the substances under study are: $8000 \mathrm{mg} / \mathrm{kg}$ for Na, $2500 \mathrm{mg} / \mathrm{kg}$ for Al, $180 \mathrm{mg} / \mathrm{kg}$ for Cr, 180 $\mathrm{mg} / \mathrm{kg}$ for Cd, $160 \mathrm{mg} / \mathrm{kg}$ for $\mathrm{Zn}$ and $170 \mathrm{mg} / \mathrm{kg}$ for Cu [42,44]. Each parameter monitored in this study was below the toxicity limits (see in Appendix A, Tables A3 and A4).

\subsection{BMP Test}

The potential biogas production was evaluated for each of the 20 reconstructed mashes, obtaining in terms of BMP, GS and percentage of $\mathrm{CH} 4$ result for each sampled collection system and for each monitored month. In terms of average values over the entire data sample, a BMP equal to $255 \pm 25$ $\mathrm{NLCH}_{4} \mathrm{~kg}_{\mathrm{TVS}}{ }^{-1}$, a GS equal to $148 \pm 18 \mathrm{Nm}^{3} \mathrm{t}_{\mathrm{OFMSW}}{ }^{-1}$ and an average percentage of $\mathrm{CH} 4$ equal to $55 \pm 0.5 \%$ were obtained (Table 6). Comparing these results to those found by other authors, it was observed that the BMP obtained was quite low when compared to the findings of Campuzano e González-Martínez, $2016\left(415 \pm 137 \mathrm{NLCH}_{4} \mathrm{~kg}_{\mathrm{TVS}}{ }^{-1}\right)$ [13] and Fisgativa et al., $2016\left(460 \pm 87 \mathrm{NLCH}_{4}\right.$ $\mathrm{kg}_{\mathrm{TVS}}{ }^{-1}$ ) [18]. The latter result is probably due to the high lignin content and low lipid content, consistent with the high content of garden waste, which having a lower production than food waste reduces the potential production of biogas [36]. The outcome is confirmed by the linear correlations, shown in Figure 7, in fact, the carbon and carbohydrate content increases when biogas production increases, whereas as the lignin content increases, BMP decreases.

Table 6. BMP test results for different collection systems $(n=4)$ and season $(n=5)$, averages, standard deviation and $p$ values.

\begin{tabular}{|c|c|c|c|c|c|c|c|c|c|}
\hline & \multicolumn{3}{|c|}{ BMP $\left(\mathrm{NLCH}_{4} \mathrm{~kg}_{\mathrm{TVS}^{-1}}\right)^{-1}$} & \multicolumn{3}{|c|}{ GS $\left(\mathrm{Nm}^{3} \mathrm{t}_{\left.\text {OFMSW }^{-1}\right)}\right.$} & \multicolumn{3}{|c|}{ CH4 (\%v/v) } \\
\hline & Mean & St. Dev. & $p$ Value & Mean & St. Dev. & $p$ Value & Mean & St. Dev. & $p$ Value \\
\hline DDR & $257.27 \mathrm{a}$ & 18.91 & \multirow{3}{*}{0.34} & $134.63 a$ & 17.05 & & $55.87 a$ & 1.44 & \multirow{3}{*}{0.66} \\
\hline DKU & $257.05 a$ & 17.15 & & $159.35 a$ & 22.06 & 0.16 & $55.78 \mathrm{a}$ & 1.09 & \\
\hline DPS & $255.25 a$ & 24.42 & & $138.90 \mathrm{a}$ & 20.82 & & $55.35 a$ & 0.09 & \\
\hline RDR & $231.70 b$ & 44.63 & \multirow{2}{*}{0.13} & $155.78 b$ & 47.46 & \multirow{2}{*}{0.72} & $54.69 \mathrm{~b}$ & 0.74 & \multirow{2}{*}{0.69} \\
\hline RVU & $294.35 b$ & 14.07 & & $141.85 b$ & 21.71 & & $54.30 \mathrm{~b}$ & 1.70 & \\
\hline March & $288.50 c, e$ & 12.36 & \multirow{5}{*}{0.02} & $172.73 \mathrm{c}$ & 27.13 & \multirow{5}{*}{0.10} & $55.33 c$ & 0.13 & \multirow{5}{*}{0.37} \\
\hline June & $228.08 d$ & 27.85 & & $146.48 \mathrm{c}$ & 11.83 & & $55.95 c$ & 1.87 & \\
\hline September & $248.05 d$ & 21.89 & & $146.70 \mathrm{c}$ & 34.61 & & $55.24 c$ & 0.19 & \\
\hline December & $255.60 \mathrm{~d}, \mathrm{e}$ & 27.63 & & $128.02 \mathrm{c}$ & 19.95 & & $54.68 c$ & 0.91 & \\
\hline Average & 255.06 & 25.14 & & 148.48 & 18.38 & & 55.30 & 0.52 & \\
\hline
\end{tabular}




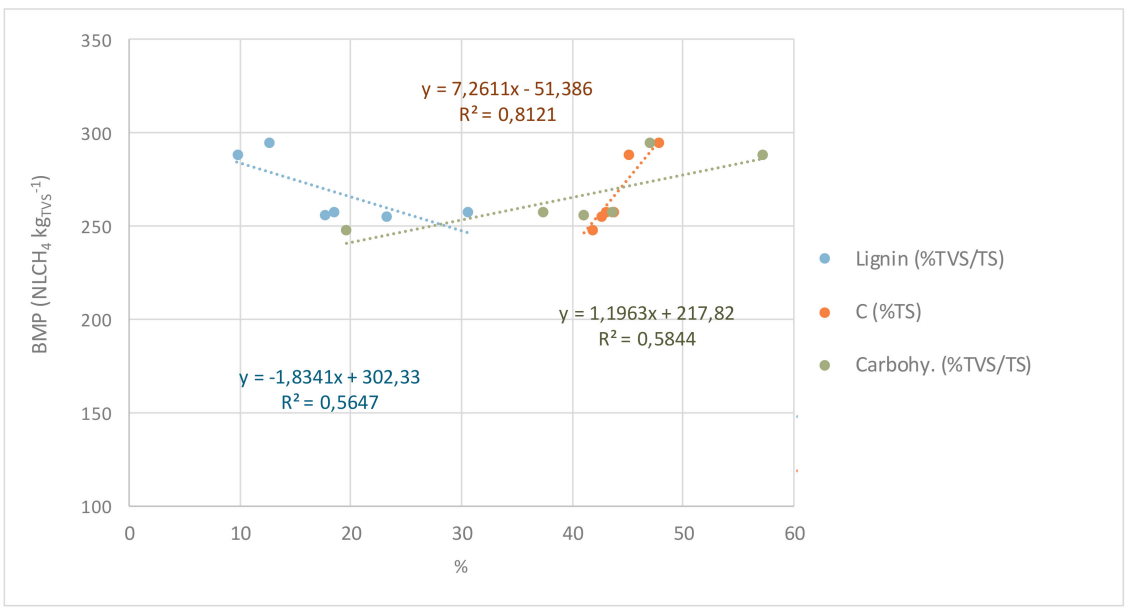

Figure 7. Linear correlation between BMP and carbohydrate, lignin and carbon (C) content.

The type of collection systems did not seem to influence BMP ( $p$ value on the 5 groups equal to 0.16 greater than 0.05 ) and even in terms of DtDS and RCS, the populations were not statistically different as can be seen from the $p$ values reported in Table 6 . Similar considerations can also be applied to GS and the methane content, which do not seem to be influenced either by the collection system or by seasonality, the only exception being for the BMP detected in the different months. In fact, from the results of the Tukey's test, pairwise, the March data correlated with the December values—and this confirms the March and December results of the colder months $\left(272 \pm 23 \mathrm{NLCH}_{4} \mathrm{~kg}_{\mathrm{TVS}}{ }^{-1}\right)$ were statistically different from those detected in the warmer months in higher temperature $(238 \pm 14$ $\mathrm{NLCH}_{4} \mathrm{~kg}_{\mathrm{TVS}}{ }^{-1}$ ). The results of GS were statistically different from BMP, as they were influenced by other factors such as the undesirable content in the analyzed mash that altered biogas production.

\section{Conclusions}

In conclusion-from the study of the characteristics of the organic fraction of municipal solid waste, depending on the collection systems and seasonality - it can be said that in both cases there are specific peculiarities.

Road container collection systems had a higher content of non-compostable and undesirable fractions $(22 \% \pm 1 \%)$ when compared to door-to-door systems $(6 \% \pm 1 \%)$. During the months with higher temperature, the garden waste content in the organic fraction of municipal solid waste was negligible, with kitchen waste prevailing. The latter result alters the physical chemical composition of organic fraction of municipal solid waste, which had a lower lignin content and higher methane production in the months with lower temperature $\left(272 \pm 23 \mathrm{NLCH}_{4} \mathrm{~kg}_{\mathrm{TVS}}{ }^{-1}\right)$ than June and September $\left(238 \pm 14 \mathrm{NLCH}_{4} \mathrm{~kg}_{\mathrm{TVS}}{ }^{-1}\right)$.

In general, the composition of Tuscan organic fraction of municipal solid waste showed a higher dry matter content $(42 \%)$ than the values obtained from previous studies. In conclusion, this result could direct possible future operators of anaerobic digestion plants towards the choice of dry and semi-dry technologies.

Author Contributions: Conceptualization, I.P. and R.I.; methodology, I.P.; software, I.P.; validation, I.P., E.R. and R.I.; formal analysis, I.P.; investigation, I.P.; resources, I.P.; data curation, E.R.; writing-original draft preparation, I.P.; writing-review and editing, I.P., E.R. and R.I.; visualization, I.P.; supervision, I.P.; project administration, I.P.; funding acquisition, I.P. All authors have read and agreed to the published version of the manuscript.

Funding: The research was co-funded by Alia Servizi Ambientali S.p.A. and Belvedere S.p.A.

Acknowledgments: The authors would like to thank Riccardo Bacci, Francesco Baldi, Elena Albini and Niccolò Frasi for their help during the field sampling. The authors would like to thank Alia Servizi Ambientali S.p.A. for hospitality and availability during sampling.

Conflicts of Interest: The authors declare no conflict of interest. 


\section{Appendix A}

Table A1. Picking analysis result for different collection systems $(n=4)$. Average and standard deviation expressed as a weight/weight percentage.

\begin{tabular}{|c|c|c|c|c|c|c|c|c|c|c|}
\hline \multirow[t]{2}{*}{ Fraction (\%) } & \multicolumn{2}{|c|}{ DDR } & \multicolumn{2}{|c|}{ DPS } & \multicolumn{2}{|c|}{ DKU } & \multicolumn{2}{|c|}{ RDR } & \multicolumn{2}{|c|}{ RVU } \\
\hline & Mean & St. Dev. & Mean & St. Dev. & Mean & St. Dev. & Mean & St. Dev. & Mean & St. Dev \\
\hline Kitchen waste & $60.76 \%$ & $16.48 \%$ & $65.66 \%$ & $6.35 \%$ & $58.09 \%$ & $19.41 \%$ & $42.53 \%$ & $8.98 \%$ & $56.32 \%$ & $16.90 \%$ \\
\hline Garden waste—lign. & $17.10 \%$ & $24.60 \%$ & $9.31 \%$ & $9.78 \%$ & $23.00 \%$ & $22.73 \%$ & $24.92 \%$ & $25.74 \%$ & $5.40 \%$ & $6.45 \%$ \\
\hline Garden waste_-grass & $8.98 \%$ & $13.60 \%$ & $1.30 \%$ & $1.74 \%$ & $3.29 \%$ & $3.25 \%$ & $5.66 \%$ & $6.99 \%$ & $6.23 \%$ & $6.25 \%$ \\
\hline Wood & $0.36 \%$ & $0.53 \%$ & $0.05 \%$ & $0.08 \%$ & $0.33 \%$ & $0.38 \%$ & $1.81 \%$ & $2.26 \%$ & $1.52 \%$ & $1.37 \%$ \\
\hline Paper & $2.10 \%$ & $1.09 \%$ & $6.91 \%$ & $2.30 \%$ & $2.22 \%$ & $1.23 \%$ & $3.43 \%$ & $1.86 \%$ & $4.03 \%$ & $2.64 \%$ \\
\hline Cardboard & $2.95 \%$ & $2.73 \%$ & $0.22 \%$ & $0.20 \%$ & $0.07 \%$ & $0.08 \%$ & $0.66 \%$ & $1.00 \%$ & $0.45 \%$ & $0.31 \%$ \\
\hline Textiles & $0.00 \%$ & $0.00 \%$ & $0.10 \%$ & $0.12 \%$ & $0.08 \%$ & $0.09 \%$ & $1.15 \%$ & $2.04 \%$ & $0.53 \%$ & $0.54 \%$ \\
\hline Diapers & $0.12 \%$ & $0.11 \%$ & $0.17 \%$ & $0.26 \%$ & $0.37 \%$ & $0.74 \%$ & $2.18 \%$ & $2.65 \%$ & $2.46 \%$ & $1.25 \%$ \\
\hline Plastic-Rigid & $1.92 \%$ & $3.26 \%$ & $2.00 \%$ & $3.88 \%$ & $1.50 \%$ & $2.86 \%$ & $2.38 \%$ & $3.26 \%$ & $0.53 \%$ & $0.63 \%$ \\
\hline Plastic_Film & $1.67 \%$ & $1.63 \%$ & $2.75 \%$ & $2.58 \%$ & $2.86 \%$ & $3.06 \%$ & $1.96 \%$ & $1.33 \%$ & $4.09 \%$ & $1.46 \%$ \\
\hline Plastic (non-packaging) & $0.04 \%$ & $0.07 \%$ & $0.00 \%$ & $0.00 \%$ & $0.11 \%$ & $0.17 \%$ & $0.13 \%$ & $0.26 \%$ & $0.77 \%$ & $0.92 \%$ \\
\hline Inert & $0.00 \%$ & $0.00 \%$ & $0.05 \%$ & $0.11 \%$ & $0.02 \%$ & $0.04 \%$ & $0.17 \%$ & $0.34 \%$ & $0.56 \%$ & $0.78 \%$ \\
\hline Metals & $0.11 \%$ & $0.13 \%$ & $0.04 \%$ & $0.04 \%$ & $1.11 \%$ & $1.94 \%$ & $0.20 \%$ & $0.20 \%$ & $0.45 \%$ & $0.13 \%$ \\
\hline Glass & $0.10 \%$ & $0.17 \%$ & $0.02 \%$ & $0.04 \%$ & $0.08 \%$ & $0.10 \%$ & $0.71 \%$ & $0.39 \%$ & $1.06 \%$ & $0.42 \%$ \\
\hline Polycoupled & $0.14 \%$ & $0.20 \%$ & $0.02 \%$ & $0.03 \%$ & $0.09 \%$ & $0.19 \%$ & $0.13 \%$ & $0.17 \%$ & $0.21 \%$ & $0.15 \%$ \\
\hline Batteries & $0.00 \%$ & $0.00 \%$ & $0.01 \%$ & $0.01 \%$ & $0.00 \%$ & $0.00 \%$ & $0.00 \%$ & $0.00 \%$ & $0.00 \%$ & $0.00 \%$ \\
\hline Drugs & $0.00 \%$ & $0.00 \%$ & $0.00 \%$ & $0.00 \%$ & $0.00 \%$ & $0.00 \%$ & $0.01 \%$ & $0.03 \%$ & $0.01 \%$ & $0.02 \%$ \\
\hline Contribution errors & $0.59 \%$ & $1.02 \%$ & $1.07 \%$ & $1.34 \%$ & $0.94 \%$ & $1.25 \%$ & $14.31 \%$ & $11.03 \%$ & $10.98 \%$ & $7.39 \%$ \\
\hline Under sieve & $3.06 \%$ & $2.22 \%$ & $10.86 \%$ & $2.01 \%$ & $6.31 \%$ & $5.79 \%$ & $4.82 \%$ & $4.96 \%$ & $4.30 \%$ & $3.66 \%$ \\
\hline Not compostable (sum) & $4.70 \%$ & $1.29 \%$ & $5.68 \%$ & $2.36 \%$ & $6.70 \%$ & $3.76 \%$ & $16.17 \%$ & $10.30 \%$ & $21.66 \%$ & $9.56 \%$ \\
\hline
\end{tabular}


Table A2. Picking analysis result for different seasons $(n=5)$. Average and standard deviation expressed as a weight/weight percentage.

\begin{tabular}{|c|c|c|c|c|c|c|c|c|}
\hline \multirow[t]{2}{*}{ Fraction } & \multicolumn{2}{|c|}{ March } & \multicolumn{2}{|c|}{ June } & \multicolumn{2}{|c|}{ September } & \multicolumn{2}{|c|}{ December } \\
\hline & Mean & St. Dev. & Mean & St. Dev. & Mean & St. Dev. & Mean & St. Dev. \\
\hline Kitchen waste & $61.77 \%$ & $15.66 \%$ & $44.84 \%$ & $9.67 \%$ & $50.43 \%$ & $16.52 \%$ & $67.57 \%$ & $7.58 \%$ \\
\hline Garden waste-lign. & $5.31 \%$ & $1.38 \%$ & $42.33 \%$ & $14.15 \%$ & $20.34 \%$ & $16.31 \%$ & $0.83 \%$ & $1.27 \%$ \\
\hline Garden waste—grass & $2.79 \%$ & $2.40 \%$ & $0.00 \%$ & $0.00 \%$ & $4.58 \%$ & $4.91 \%$ & $10.51 \%$ & $9.61 \%$ \\
\hline Wood & $1.34 \%$ & $2.45 \%$ & $0.26 \%$ & $0.47 \%$ & $1.07 \%$ & $1.16 \%$ & $0.54 \%$ & $0.78 \%$ \\
\hline Paper & $4.30 \%$ & $1.78 \%$ & $1.91 \%$ & $1.51 \%$ & $3.44 \%$ & $3.06 \%$ & $5.32 \%$ & $2.44 \%$ \\
\hline Cardboard & $0.78 \%$ & $0.95 \%$ & $1.35 \%$ & $2.70 \%$ & $0.91 \%$ & $1.44 \%$ & $0.18 \%$ & $0.19 \%$ \\
\hline Textiles & $0.23 \%$ & $0.18 \%$ & $0.04 \%$ & $0.08 \%$ & $1.12 \%$ & $1.79 \%$ & $0.06 \%$ & $0.08 \%$ \\
\hline Diapers & $0.62 \%$ & $0.85 \%$ & $0.33 \%$ & $0.53 \%$ & $2.32 \%$ & $2.66 \%$ & $0.64 \%$ & $0.66 \%$ \\
\hline Plastic-Rigid & $0.33 \%$ & $0.37 \%$ & $0.08 \%$ & $0.15 \%$ & $5.30 \%$ & $3.10 \%$ & $0.54 \%$ & $0.59 \%$ \\
\hline Plastic_Film & $1.87 \%$ & $1.07 \%$ & $3.50 \%$ & $0.79 \%$ & $0.70 \%$ & $1.55 \%$ & $4.53 \%$ & $2.06 \%$ \\
\hline Plastic (non-packaging) & $0.10 \%$ & $0.20 \%$ & $0.09 \%$ & $0.18 \%$ & $0.49 \%$ & $0.77 \%$ & $0.03 \%$ & $0.05 \%$ \\
\hline Inert & $0.25 \%$ & $0.30 \%$ & $0.00 \%$ & $0.00 \%$ & $0.33 \%$ & $0.63 \%$ & $0.00 \%$ & $0.00 \%$ \\
\hline Metals & $0.21 \%$ & $0.17 \%$ & $1.00 \%$ & $2.01 \%$ & $0.23 \%$ & $0.17 \%$ & $0.21 \%$ & $0.21 \%$ \\
\hline Glass & $0.40 \%$ & $0.47 \%$ & $0.18 \%$ & $0.28 \%$ & $0.53 \%$ & $0.51 \%$ & $0.35 \%$ & $0.63 \%$ \\
\hline Polycoupled & $0.05 \%$ & $0.07 \%$ & $0.19 \%$ & $0.22 \%$ & $0.05 \%$ & $0.12 \%$ & $0.16 \%$ & $0.16 \%$ \\
\hline Batteries & $0.00 \%$ & $0.00 \%$ & $0.00 \%$ & $0.00 \%$ & $0.00 \%$ & $0.00 \%$ & $0.01 \%$ & $0.01 \%$ \\
\hline Drugs & $0.00 \%$ & $0.00 \%$ & $0.00 \%$ & $0.00 \%$ & $0.02 \%$ & $0.03 \%$ & $0.00 \%$ & $0.00 \%$ \\
\hline Contribution errors & $8.39 \%$ & $9.99 \%$ & $0.00 \%$ & $0.00 \%$ & $9.52 \%$ & $8.52 \%$ & $2.95 \%$ & $2.54 \%$ \\
\hline Under sieve & $11.27 \%$ & $3.54 \%$ & $3.90 \%$ & $4.26 \%$ & $4.28 \%$ & $4.66 \%$ & $5.58 \%$ & $2.94 \%$ \\
\hline Not compostable (sum) & $12.44 \%$ & $2.81 \%$ & $5.41 \%$ & $0.57 \%$ & $20.62 \%$ & $2.40 \%$ & $9.47 \%$ & $0.85 \%$ \\
\hline
\end{tabular}


Table A3. Nutritional elements and metal analysis for different collection systems $(n=4)$.

\begin{tabular}{|c|c|c|c|c|c|c|c|c|c|c|}
\hline \multirow[t]{2}{*}{ (mg/Kg) } & \multicolumn{2}{|c|}{ DDR } & \multicolumn{2}{|c|}{ DKU } & \multicolumn{2}{|c|}{ DPS } & \multicolumn{2}{|c|}{ RDR } & \multicolumn{2}{|c|}{ RVU } \\
\hline & Mean & St. Dev. & Mean & St. Dev. & Mean & St. Dev. & Mean & St. Dev. & Mean & St. Dev. \\
\hline \multicolumn{11}{|c|}{ Nutritional elements } \\
\hline $\mathrm{NH} 3-\mathrm{N}$ & 293.51 & 195.67 & 492.45 & 344.33 & 411.01 & 345.03 & 259.65 & 218.22 & 765.00 & 49.50 \\
\hline $\mathrm{Ca}$ & 8255.28 & 7279.17 & 7183.31 & 6956.27 & 8012.96 & 6622.56 & 7411.93 & 5716.07 & 4925.00 & 49.50 \\
\hline $\mathrm{P}$ & 584.38 & 97.55 & 806.94 & 135.21 & 630.93 & 85.87 & 667.54 & 58.71 & 729.50 & 262.34 \\
\hline $\mathrm{Na}$ & 1305.26 & 929.93 & 1580.08 & 899.11 & 1510.42 & 1132.35 & 1335.00 & 692.15 & 1310.00 & 0.00 \\
\hline K & 2260.91 & 241.60 & 2539.83 & 234.14 & 2259.53 & 179.31 & 2497.56 & 376.34 & 2115.00 & 7.07 \\
\hline $\mathrm{Fe}$ & 764.25 & 512.97 & 3335.81 & 5051.71 & 576.69 & 330.21 & 585.28 & 412.97 & 257.00 & 197.99 \\
\hline $\mathrm{Mn}$ & 50.11 & 36.39 & 185.97 & 283.11 & 28.89 & 11.90 & 45.82 & 17.04 & 13.50 & 2.12 \\
\hline $\mathrm{Mg}$ & 768.38 & 409.05 & 844.96 & 813.70 & 873.41 & 283.79 & 663.13 & 279.00 & 945.00 & 770.75 \\
\hline Mo & 1.83 & 0.30 & 1.00 & 0.40 & 1.43 & 0.51 & 1.35 & 0.47 & 1.50 & 0.71 \\
\hline $\mathrm{Zn}$ & 13.45 & 7.68 & 218.06 & 401.31 & 13.67 & 6.24 & 18.29 & 7.03 & 10.50 & 4.95 \\
\hline \multicolumn{11}{|l|}{ Metals } \\
\hline As & 0.70 & 0.52 & 0.55 & 0.52 & 0.33 & 0.45 & 0.33 & 0.45 & 0.10 & 0.00 \\
\hline $\mathrm{Al}$ & 483.53 & 406.41 & 383.87 & 111.01 & 539.39 & 190.12 & 359.01 & 252.60 & 324.00 & 248.90 \\
\hline $\mathrm{Ba}$ & 10.41 & 4.69 & 18.04 & 14.45 & 11.99 & 4.09 & 18.63 & 13.77 & 31.50 & 31.82 \\
\hline $\mathrm{Cr}$ & 2.32 & 1.53 & 2.74 & 2.22 & 1.86 & 1.02 & 1.95 & 0.82 & 2.50 & 2.12 \\
\hline $\mathrm{Cd}$ & 0.01 & 0.01 & 0.01 & 0.01 & 0.01 & 0.01 & 1.00 & 0.01 & 0.01 & 0.01 \\
\hline $\mathrm{Cu}$ & 5.84 & 3.34 & 610.38 & 1206.42 & 6.82 & 2.95 & 6.90 & 2.43 & 3.50 & 0.71 \\
\hline $\mathrm{Ni}$ & 2.52 & 1.83 & 3.51 & 2.09 & 1.78 & 1.02 & 3.61 & 3.35 & 0.75 & 0.35 \\
\hline $\mathrm{Pb}$ & 1.69 & 1.19 & 1.76 & 0.98 & 3.04 & 2.62 & 3.81 & 3.02 & $<1$ & \\
\hline $\mathrm{Hg}$ & 0.5 & 0 & 5.625 & 10.25 & 0.5 & 0 & 0.5 & 0.00 & 0.50 & 0.00 \\
\hline
\end{tabular}


Table A4. Nutritional elements and metal analysis for different seasons $(n=5)$.

\begin{tabular}{|c|c|c|c|c|c|c|c|c|c|c|}
\hline \multirow[t]{2}{*}{$(\mathrm{mg} / \mathrm{Kg})$} & \multicolumn{2}{|c|}{ March } & \multicolumn{2}{|c|}{ June } & \multicolumn{2}{|c|}{ September } & \multicolumn{2}{|c|}{ December } & \multicolumn{2}{|c|}{ Average } \\
\hline & Mean & St. Dev. & Mean & St. Dev. & Mean & St. Dev. & Mean & St. Dev. & Media & St. Dev. \\
\hline \multicolumn{11}{|c|}{ Nutritional elements } \\
\hline $\mathrm{NH}_{3}-\mathrm{N}$ & 772.25 & 230.02 & 461.00 & 31.72 & 176.75 & 170.55 & 284.60 & 257.16 & 423.65 & 260.26 \\
\hline $\mathrm{Ca}$ & 4130.00 & 582.69 & $16,397.41$ & 1050.55 & 4462.25 & 3011.12 & 6078.00 & 1134.87 & 7766.92 & 5816.24 \\
\hline $\mathrm{P}$ & 821.75 & 89.18 & 644.70 & 9.14 & 591.00 & 119.90 & 618.00 & 43.98 & 668.86 & 104.26 \\
\hline $\mathrm{Na}$ & 1572.50 & 562.75 & 2506.19 & 484.62 & 670.75 & 154.89 & 1048.00 & 217.99 & 1449.36 & 795.69 \\
\hline $\mathrm{K}$ & 2145.00 & 189.82 & 2426.11 & 9.83 & 2459.00 & 455.99 & 2416.00 & 228.10 & 2361.53 & 145.51 \\
\hline $\mathrm{Fe}$ & 285.50 & 130.44 & 1019.21 & 185.46 & 596.75 & 432.31 & 503.40 & 320.96 & 601.22 & 307.67 \\
\hline $\mathrm{Mn}$ & 22.75 & 12.37 & 56.51 & 10.53 & 31.00 & 17.63 & 38.00 & 27.80 & 37.06 & 14.38 \\
\hline $\mathrm{Mg}$ & 647.50 & 389.99 & 885.53 & 80.89 & 693.50 & 369.38 & 916.00 & 385.07 & 785.63 & 134.84 \\
\hline Mo & 1.00 & 0.00 & 1.52 & 0.14 & 1.25 & 0.50 & 2.80 & 1.79 & 1.64 & 0.80 \\
\hline $\mathrm{Zn}$ & 11.75 & 2.63 & 20.61 & 2.77 & 17.25 & 8.18 & 10.00 & 3.74 & 14.90 & 4.90 \\
\hline \multicolumn{11}{|l|}{ Metals } \\
\hline As & 0.10 & 0.00 & 1.00 & 0.00 & 0.10 & 0.00 & 0.46 & 0.49 & 0.42 & 0.43 \\
\hline $\mathrm{Al}$ & 350.25 & 214.84 & 442.16 & 76.45 & 332.50 & 327.75 & 545.60 & 229.97 & 417.63 & 97.92 \\
\hline Ва & 34.25 & 18.71 & 12.73 & 1.94 & 14.50 & 7.77 & 10.50 & 1.91 & 17.99 & 10.96 \\
\hline $\mathrm{Cr}$ & 1.50 & 0.58 & 2.04 & 0.28 & 2.75 & 2.36 & 2.60 & 1.52 & 2.22 & 0.57 \\
\hline $\mathrm{Cd}$ & 0.01 & 0.01 & 0.01 & 0.01 & 0.01 & 0.01 & 0.01 & 0.01 & 0.01 & 0.01 \\
\hline $\mathrm{Cu}$ & 5.00 & 1.15 & 9.48 & 0.14 & 6.50 & 2.65 & 4.00 & 1.41 & 6.25 & 2.39 \\
\hline $\mathrm{Ni}$ & 0.88 & 0.25 & 3.92 & 0.55 & 3.38 & 3.25 & 1.40 & 0.89 & 2.39 & 1.48 \\
\hline $\mathrm{Pb}$ & $<1$ & & 2.92 & 0.55 & 4.00 & 2.94 & 1.00 & 0.00 & 2.23 & 1.49 \\
\hline $\mathrm{Hg}$ & 0.50 & 0.00 & 0.50 & 0.00 & 0.50 & 0.00 & 0.50 & 0.00 & 0.50 & 0.00 \\
\hline
\end{tabular}




\section{References}

1. EUR-Lex-52010DC0235-EN. Available online: https:/eur-lex.europa.eu/legal-content/EN/TXT/HTML/?uri= CELEX:52010DC0235\&from=EN (accessed on 8 March 2020).

2. Rapporto Rifiuti Urbani-Edizione 2019. Available online: http://www.isprambiente.gov.it/it/pubblicazioni/ rapporti/rapporto-rifiuti-urbani-edizione-2019 (accessed on 8 March 2020).

3. EUR-Lex-52015DC0614-EN-EUR-Lex. Available online: https://eur-lex.europa.eu/legal-content/EN/TXT/ ?uri=CELEX\%3A52015DC0614 (accessed on 8 March 2020).

4. Baldi, F.; Pecorini, I.; Iannelli, R. Comparison of single-stage and two-stage anaerobic co-digestion of food waste and activated sludge for hydrogen and methane production. Renew. Energy 2019, 143, 1755-1765. [CrossRef]

5. Union, P.O. of the E. A Sustainable Bioeconomy for Europe: Strengthening the Connection between Economy, Society and the Environment: Updated Bioeconomy Strategy. Available online: https://op.europa.eu: 443/en/publication-detail/-/publication/edace3e3-e189-11e8-b690-01aa75ed71a1/language-en (accessed on 6 February 2020).

6. Demichelis, F.; Piovano, F.; Fiore, S. Biowaste Management in Italy: Challenges and Perspectives. Sustainability 2019, 11, 4213. [CrossRef]

7. Tyagi, V.K.; Fdez-Güelfo, L.A.; Zhou, Y.; Álvarez-Gallego, C.J.; Garcia, L.I.R.; Ng, W.J. Anaerobic co-digestion of organic fraction of municipal solid waste (OFMSW): Progress and challenges. Renew. Sustain. Energy Rev. 2018, 93, 380-399. [CrossRef]

8. Angelidaki, I.; Chen, X.; Cui, J.; Kaparaju, P.; Ellegaard, L. Thermophilic anaerobic digestion of source-sorted organic fraction of household municipal solid waste: Start-up procedure for continuously stirred tank reactor. Water Res. 2006, 40, 2621-2628. [CrossRef]

9. Fernández-Rodríguez, J.; Pérez, M.; Romero, L.I. Comparison of mesophilic and thermophilic dry anaerobic digestion of OFMSW: Kinetic analysis. Chem. Eng. J. 2013, 232, 59-64. [CrossRef]

10. Beggio, G.; Schievano, A.; Bonato, T.; Hennebert, P.; Pivato, A. Statistical analysis for the quality assessment of digestates from separately collected organic fraction of municipal solid waste (OFMSW) and agro-industrial feedstock. Should input feedstock to anaerobic digestion determine the legal status of digestate? Waste Manag. 2019, 87, 546-558. [CrossRef]

11. Zhang, R.; Elmashad, H.; Hartman, K.; Wang, F.; Liu, G.; Choate, C.; Gamble, P. Characterization of food waste as feedstock for anaerobic digestion. Bioresour. Technol. 2007, 98, 929-935. [CrossRef]

12. Melts, I.; Normak, A.; Nurk, L.; Heinsoo, K. Chemical characteristics of biomass from nature conservation management for methane production. Bioresour. Technol. 2014, 167, 226-231. [CrossRef]

13. Campuzano, R.; González-Martínez, S. Characteristics of the organic fraction of municipal solid waste and methane production: A review. Waste Manag. 2016, 54, 3-12. [CrossRef]

14. Xu, F.; Wang, Z.-W.; Li, Y. Predicting the methane yield of lignocellulosic biomass in mesophilic solid-state anaerobic digestion based on feedstock characteristics and process parameters. Bioresour. Technol. 2014, 173, 168-176. [CrossRef]

15. Long, G.; Liu, S.; Xu, G.; Wong, S.-W.; Chen, H.; Xiao, B. A Perforation-Erosion Model for Hydraulic-Fracturing Applications. SPE Prod. Oper. 2018, 33, 770-783. [CrossRef]

16. Xiao, B.; Wang, W.; Zhang, X.; Long, G.; Fan, J.; Chen, H.; Deng, L. A novel fractal solution for permeability and Kozeny-Carman constant of fibrous porous media made up of solid particles and porous fibers. Powder Technol. 2019, 349, 92-98. [CrossRef]

17. Xiao, B.; Zhang, X.; Jiang, G.; Long, G.; Wang, W.; Zhang, Y.; Liu, G. KOZENY-CARMAN CONSTANT FOR GAS FLOW THROUGH FIBROUS POROUS MEDIA BY FRACTAL-MONTE CARLO SIMULATIONS. Fractals 2019, 27, 1950062. [CrossRef]

18. Fisgativa, H.; Tremier, A.; Dabert, P. Characterizing the variability of food waste quality: A need for efficient valorisation through anaerobic digestion. Waste Manag. 2016, 50, 264-274. [CrossRef] [PubMed]

19. Pecorini, I.; Baldi, F.; Albini, E.; Galoppi, G.; Bacchi, D.; Valle, A.D.; Baldi, A.; Bianchini, A.; Figini, A.; Rossi, P.; et al. Hydrogen production from food waste using biochemical hydrogen potential test. Procedia Environ. Sci. Eng. Manag. 2017, 4, 155-162. 
20. Bernstad, A.; la Cour Jansen, J. Separate collection of household food waste for anaerobic degradation-Comparison of different techniques from a systems perspective. Waste Manag. 2012, 32, 806-815. [CrossRef]

21. Browne, J.D.; Murphy, J.D. Assessment of the resource associated with biomethane from food waste. Appl. Energy 2013, 104, 170-177. [CrossRef]

22. Hla, S.S.; Roberts, D. Characterisation of chemical composition and energy content of green waste and municipal solid waste from Greater Brisbane, Australia. Waste Manag. 2015, 41, 12-19. [CrossRef]

23. Azam, M.; Jahromy, S.S.; Raza, W.; Raza, N.; Lee, S.S.; Kim, K.-H.; Winter, F. Status, characterization, and potential utilization of municipal solid waste as renewable energy source: Lahore case study in Pakistan. Environ. Int. 2020, 134, 105291. [CrossRef]

24. Pecorini, I.; Bacchi, D.; Albini, E.; Baldi, F.; Galoppi, G.; Rossi, P.; Paoli, P.; Ferrari, L.; Carnevale, E.A.; Peruzzini, M.; et al. The bio2energy project: Bioenergy, biofuels and bioproducts from municipal solid waste and sludge. In Proceedings of the 25th European Biomass Conference and Exhibition, Stockholm, Sweden, 12-15 June 2017; Volume 2017, pp. 70-77.

25. Morlok, J.; Schoenberger, H.; Styles, D.; Galvez-Martos, J.-L.; Zeschmar-Lahl, B. The Impact of Pay-As-You-Throw Schemes on Municipal Solid Waste Management: The Exemplar Case of the County of Aschaffenburg, Germany. Resources 2017, 6, 8. [CrossRef]

26. Gallardo, A.; Prades, M.; Bovea, M.D.; Colomer, F.J. Separate Collection Systems for Urban Waste (UW). In Management of Organic Waste; Kumar, S., Ed.; InTech: London, UK, 2012.

27. Nappi, P.; Valenzano, F.; Consiglio, M.; Piemonte, A. Analisi merceologica dei rifiuti urbani Rassegna di metodologie e definizione di una metodica di riferimento. Available online: https://www.arpal.liguria.it/ files/rifiuti/ANPA_Merceologia.pdf (accessed on 7 March 2020).

28. Hansen, T.L.; la Cour Jansen, J.; Spliid, H.; Davidsson, Å.; Christensen, T.H. Composition of source-sorted municipal organic waste collected in Danish cities. Waste Manag. 2007, 27, 510-518. [CrossRef] [PubMed]

29. Pecorini, I.; Iannelli, R. Characterization of Excavated Waste of Different Ages in View of Multiple Resource Recovery in Landfill Mining. Sustainability 2020, 12, 1780. [CrossRef]

30. Pecorini, I.; Bacchi, D.; Iannelli, R. Biodrying of the Light Fraction from Anaerobic Digestion Pretreatment in Order to Increase the Total Recovery Rate. Processes 2020, 8, 276. [CrossRef]

31. Metodi di Analisi del Compost. Available online: http://www.isprambiente.gov.it/it/pubblicazioni/manualie-linee-guida/metodi-di-analisi-del-compost (accessed on 1 March 2020).

32. Pecorini, I.; Baldi, F.; Carnevale, E.A.; Corti, A. Biochemical methane potential tests of different autoclaved and microwaved lignocellulosic organic fractions of municipal solid waste. Waste Manag. 2016, 56, 143-150. [CrossRef] [PubMed]

33. Naroznova, I.; Møller, J.; Scheutz, C. Characterisation of the biochemical methane potential (BMP) of individual material fractions in Danish source-separated organic household waste. Waste Manag. 2016, 50, 39-48. [CrossRef]

34. Angelidaki, I.; Alves, M.; Bolzonella, D.; Borzacconi, L.; Campos, J.L.; Guwy, A.J.; Kalyuzhnyi, S.; Jenicek, P.; van Lier, J.B. Defining the biomethane potential (BMP) of solid organic wastes and energy crops: A proposed protocol for batch assays. Water Sci. Technol. 2009, 59, 927-934. [CrossRef] [PubMed]

35. Pecorini, I.; Baldi, F.; Iannelli, R. Biochemical Hydrogen Potential Tests Using Different Inocula. Sustainability 2019, 11, 622. [CrossRef]

36. Pecorini, I.; Olivieri, T.; Bacchi, D.; Paradisi, A.; Lombardi, L.; Corti, A.; Carnevale, E. Evaluation of gas production in a industrial anaerobic digester by means of biochemical methane potential of organic municipal solid waste components. In Proceedings of the 25th International Conference on Efficiency, Cost, Optimization, Simulation and Environmental Impact of Energy Systems, Perugia, Italy, 26-29 June 2012; Volume 5, pp. 173-184.

37. Pecorini, I.; Baldi, F.; Carnevale, E.A.; Corti, A. Enhancement of methane production of microwaved pretreated biowaste at different enthalpies. In Proceedings of the 28th International Conference on Efficiency, Cost, Optimization, Simulation and Environmental Impact of Energy Systems, ECOS 2015, Pau, France, 29 June-3 July 2015.

38. Baldi, F.; Iannelli, R.; Pecorini, I.; Polettini, A.; Pomi, R.; Rossi, A. Influence of the pH control strategy and reactor volume on batch fermentative hydrogen production from the organic fraction of municipal solid waste. Waste Manag. Res. 2019, 37, 478-485. [CrossRef] 
39. Cesaro, A.; Russo, L.; Belgiorno, V. Combined anaerobic/aerobic treatment of OFMSW: Performance evaluation using mass balances. Chem. Eng. J. 2015, 267, 16-24. [CrossRef]

40. Alvarez, M.D.; Sans, R.; Garrido, N.; Torres, A. Factors that affect the quality of the bio-waste fraction of selectively collected solid waste in Catalonia. Waste Manag. 2008, 28, 359-366. [CrossRef]

41. López, M.; Soliva, M.; Martínez-Farré, F.X.; Fernández, M.; Huerta-Pujol, O. Evaluation of MSW organic fraction for composting: Separate collection or mechanical sorting. Resour. Conserv. Recycl. 2010, 54, 222-228. [CrossRef]

42. Chen, Y.; Cheng, J.J.; Creamer, K.S. Inhibition of anaerobic digestion process: A review. Bioresour. Technol. 2008, 99, 4044-4064. [CrossRef] [PubMed]

43. Iacovidou, E.; Ohandja, D.-G.; Voulvoulis, N. Food waste co-digestion with sewage sludge-Realising its potential in the UK. J. Environ. Manag. 2012, 112, 267-274. [CrossRef] [PubMed]

44. APAT Digestione Anaerobica Della Frazione Organica dei Rifiuti Solidi. Available online: http://www.isprambiente.gov.it/it/pubblicazioni/manuali-e-linee-guida/digestione-anaerobica-dellafrazione-organica-dei (accessed on 7 March 2020).

(C) 2020 by the authors. Licensee MDPI, Basel, Switzerland. This article is an open access article distributed under the terms and conditions of the Creative Commons Attribution (CC BY) license (http://creativecommons.org/licenses/by/4.0/). 